\title{
Recognition Methods Research On Flood damage Of Highway Slope In
}

\section{Mountainous areas}

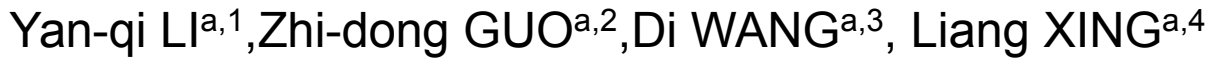 \\ ${ }^{a}$ College of Civil\&Transpotation Engineering,Hebei University of Technology,Tianjin300401,China \\ 1Email:57492858@qq.com \\ 2Email:jxxlbgzd@126.com \\ ${ }^{3}$ Corresponding author:Di WANG,Email:57492858@qq.com \\ [Email:303188523@qq.com
}

key words mountainous highway, upper slope ,flood damage,

Abstract This paper introduces the effect factors of flood damage of highway upper slope in mountainous areas, predicting model and main points of identification technique. Combining with the application example of north mountainous area by Jizhou District, shows the method's validity and practicability.

The flood damage of highway upper slope in mountainous areas often caused by strong precipitation process. Displacement of soil slope phenomena are extremely popular, where there is slope, there is movement of rock and soil slope. Combining internal stress of rock mass and external stress such as a strong precipitation, to form to slump, and lead to the destruction of along the highway.

Result and Analysis on investigation about flood damage losses of highway in the whole area, researchers found there were 67 flood damages in recent 3 years. Among those, pavement damages, highways and bridges destroyed, Pavement damages initiated by slump and by debris flow respectively were $55 \%, 37 \%, 5 \%$ and $3 \%$. The frequency comparison of all kinds of the flood damages of highway in the area shown in FIG 1.

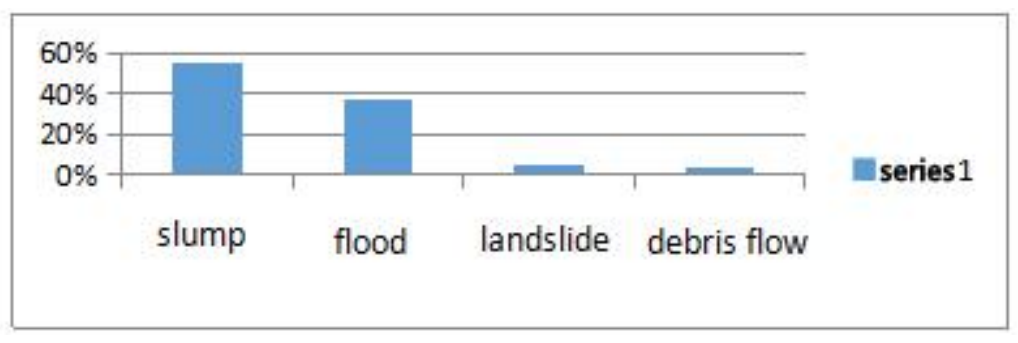

\section{The flood damage of slope evaluation factors}

The flood damage of highway slope in mountainous areas often caused by the slope runoff generated by strong rainfall , and the infiltration process. The size of radial flow of slope determines the damage degree of flood damage of slope to existed highway slope. Considering the main influencing factors of the mechanism, the researchers selected four factors, such as rainfall factor, terrain slope factor, geotechnical type factor and vegetation coverage factor, to evaluate the strength of slope runoff.

(1)Rainfall factors $(\mathrm{J})$ 
The short duration heavy rainfall in Tianjin mountainous areas is more common, and the $24 \mathrm{~h}$ rainfall of $25 \mathrm{~mm}$ may cause serious highway slope disaster. According to the expert survey, the research group selected the index of "annual average rainfall greater than $25 \mathrm{~mm}$ days" to reflect the effect and influence of rainfall factor, and divided into five grades, the impact of the value shown in Table 1.

Table1 Rainfall factor classification table

\begin{tabular}{|c|c|c|c|c|c|}
\hline $\begin{array}{c}\text { Grade of rainfall } \\
\text { factors }(\mathrm{J})\end{array}$ & $<1 \mathrm{~d}$ & $1 \sim 3 \mathrm{~d}$ & $3 \sim 7 \mathrm{~d}$ & $7 \sim 15 \mathrm{~d}$ & $>15 \mathrm{~d}$ \\
\hline influence degree & weak & weaker & medium & stronger & strong \\
\hline influence value & 0.10 & 0.25 & 0.50 & 0.75 & 0.90 \\
\hline
\end{tabular}

(2) Topographic slope factor

Slope is an important parameter to reflect the terrain factors. Combining with the grading requirements of highway project on terrain slope, the influence of terrain slope factor on slope runoff intensity is divided into five levels and endow the influence value, shown in Table 2.

Table 2 terrain slope factor classification table

\begin{tabular}{|l|c|c|c|c|c|}
\hline $\begin{array}{l}\text { Grade of terrain } \\
\text { slope factor }(\mathrm{J})\end{array}$ & $0^{\circ} \sim 6^{\circ}$ & $6^{\circ} \sim 15^{\circ}$ & $15^{\circ} \sim 25^{\circ}$ & $25^{\circ} \sim 35^{\circ}$ & $>35^{\circ}$ \\
\hline influence degree & weak & weaker & medium & stronger & strong \\
\hline influence value & 0.05 & 0.20 & 0.40 & 0.75 & 0.90 \\
\hline
\end{tabular}

(3) Rock type factor (Y)

For different types of rock and soil mass, when the ability of resistance to erosion is strong, infiltration rate is low; that is easily to promote overland flow, erosion intensity is small. According to the experts' opinion, the influence degree of rock type on slope runoff intensity is divided into five grades. Shown in Table 3.

Table 3 geotechnical type factor classification table

\begin{tabular}{|c|c|c|c|c|c|}
\hline $\begin{array}{l}\text { Grade of geotechnical } \\
\text { type factor (Y) }\end{array}$ & hard rock & $\begin{array}{c}\text { Gravel Soil, } \\
\text { extremely soft rock }\end{array}$ & $\begin{array}{c}\text { cohesive } \\
\text { soil }\end{array}$ & sand formation & $\begin{array}{c}\text { Loess、silty } \\
\text { soil }\end{array}$ \\
\hline influence degree & weak & weaker & medium & stronger & strong \\
\hline influence value & 0.10 & 0.40 & 0.60 & 0.75 & 0.90 \\
\hline
\end{tabular}

(4) Vegetation coverage factor $(Z)$

According to the experts' opinion survey, the study group divided the vegetation type and coverage degree on the slope runoff intensity into five grades, the impact of which is shown in Table 4.

Table 4 Vegetation coverage factor classification table

\begin{tabular}{|c|c|c|c|c|c|}
\hline $\begin{array}{l}\text { Grade of Vegetation } \\
\text { coverage factor }(\mathrm{Z})\end{array}$ & $>80 \%$ & $50 \% \sim 80 \%$ & $20 \%{ }^{\circ} \sim 50 \%$ & $5 \% \sim 20 \%$ & $0 \% \sim 5 \%$ \\
\hline influence degree & weak & weaker & medium & stronger & strong \\
\hline influence value & 0 & 0.10 & 0.50 & 0.75 & 1.00 \\
\hline
\end{tabular}

\section{Flood damage of slope assessment model}

The study team used the index of the slope runoff intensity to representation of slope runoff intensity, considering rainfall factor $(\mathrm{J})$, terrain slope factor $(\mathrm{D})$, rock type factor $(\mathrm{Y})$ and vegetation coverage factor $(Z)$ to calculate slope runoff intensity index. The calculation model is as follows:

$$
\mathrm{P}=\mathrm{a}_{1} \times \mathrm{J}+\mathrm{a}_{2} \times \mathrm{D}+\mathrm{a}_{3} \times \mathrm{Y}+\mathrm{a}_{4} \times \mathrm{Z}
$$

(Equation 2-1) 
$\mathrm{P}$ represents the slope runoff intensity index; J, D, Y, and $\mathrm{Z}$ represent the influence degree of rainfall, terrain slope, rock type and vegetation coverage respectively. $a_{1}, a_{2}, a_{3}, a_{4}$ represent the weight coefficients of rainfall, terrain slope, rock type and vegetation coverage.

The weight determination method uses AHP, through the expert opinion survey, the analysis and calculation of the impact factor weight value shown in Table 5.

Table 5 the impact of each factor weight table

\begin{tabular}{|l|c|c|c|c|}
\hline factor weight & $\begin{array}{c}\text { rainfall factor } \\
(\mathrm{J})\end{array}$ & $\begin{array}{c}\text { terrain slope factor } \\
(\mathrm{D})\end{array}$ & $\begin{array}{c}\text { vegetation coverage } \\
\text { factor }(\mathrm{Z})\end{array}$ & rock type factor $(\mathrm{Y})$ \\
\hline weight value & 0.35 & 0.30 & 0.15 & 0.20 \\
\hline
\end{tabular}

cording to the regional distribution characteristics of runoff intensity index $(\mathrm{P})$, the slope runoff intensity can be divided into weak, medium and strong level. According to the formula 4-1, the calculated range is between 0.055 and 0.915 , The corresponding level of runoff intensity range to the possibility of flood damage correspondence as shown in Table 6 .

Table 6 slope runoff intensity index corresponds to the possibility of highway flood damage

\begin{tabular}{|c|c|c|c|}
\hline Grade of slope runoff intensity index & weak & medium & strong \\
\hline P & $0.055 \sim 0.35$ & $0.35 \sim 0.45$ & $0.45 \sim 0.915$ \\
\hline Possibility of flooding disaster of highway slope & Less occurs & May happen & Prone to happen \\
\hline
\end{tabular}

The application of north mountainous area by Jizhou District evaluation model analysis

Researchers have taken the comprehensive investigation those 9 roads below and other roads in mountainous areas. The duration is about 15 days, getting 12 slope hazard points, the basic data information is as follows:

Table 7 The basis data of mountain flood damage risk table

\begin{tabular}{|c|c|c|c|c|c|c|c|c|}
\hline Highway name & $\begin{array}{l}\text { Types of } \\
\text { geotechnical }\end{array}$ & $\begin{array}{l}\text { Geotech } \\
\text { nical } \\
\text { type } \\
\text { factor } \\
\text { influence }\end{array}$ & $\begin{array}{l}\text { Terrain } \\
\text { slope }\end{array}$ & $\begin{array}{l}\text { Terrain } \\
\text { slope } \\
\text { factor } \\
\text { influence }\end{array}$ & $\begin{array}{l}\text { rainfall is } \\
\text { greater } \\
\text { than } 25 \mathrm{~mm} \\
\text { days }\end{array}$ & $\begin{array}{l}\text { Rainfall } \\
\text { factor } \\
\text { influence }\end{array}$ & $\begin{array}{l}\text { Vegetation } \\
\text { coverage }\end{array}$ & $\begin{array}{l}\text { Vegetation } \\
\text { coverage } \\
\text { factor } \\
\text { influence }\end{array}$ \\
\hline $\begin{array}{l}\text { North Jinwei } \\
\text { Road }\end{array}$ & Gravel Soil & 0.40 & $60^{\circ}$ & 0.9 & $12 \mathrm{~d}$ & 0.75 & $75 \%$ & 0.1 \\
\hline $\begin{array}{l}\text { Sangyuan } \\
\text { Section, } \\
\text { Maping Road }\end{array}$ & Gravel Soil & 0.40 & $55^{\circ}$ & 0.9 & $11 \mathrm{~d}$ & 0.75 & $82 \%$ & 0 \\
\hline $\begin{array}{l}\text { Xinshui } \\
\text { chang Section, } \\
\text { Yulong Road }\end{array}$ & $\begin{array}{l}\text { Gravel Soil, } \\
\text { extremely } \\
\text { soft rock }\end{array}$ & 0.40 & $57^{\circ}$ & 0.9 & $9 d$ & 0.75 & $77 \%$ & 0.1 \\
\hline $\begin{array}{l}\text { Yangjiayu } \\
\text { Section, } \\
\text { Luoyang Road }\end{array}$ & $\begin{array}{l}\text { Gravel Soil, } \\
\text { extremely } \\
\text { soft rock }\end{array}$ & 0.40 & $62^{\circ}$ & 0.9 & $11 d$ & 0.75 & $83 \%$ & 0 \\
\hline $\begin{array}{l}\text { Chuancangyu } \\
\text { Section, } \\
\text { Limutai } \\
\text { Jingguan Road }\end{array}$ & Gravel Soil & 0.40 & $66^{\circ}$ & 0.9 & $12 \mathrm{~d}$ & 0.75 & $74 \%$ & 0.1 \\
\hline $\begin{array}{l}\text { Gan Jian } \\
\text { Section in the } \\
\text { front of Jin } \\
\text { Qian Road }\end{array}$ & hard rock & 0.10 & $59^{\circ}$ & 0.9 & $12 \mathrm{~d}$ & 0.75 & $81 \%$ & 0 \\
\hline $\begin{array}{l}\text { Guoxi Section, } \\
\text { Guoying Road }\end{array}$ & hard rock & 0.10 & $71^{\circ}$ & 0.9 & $10 \mathrm{~d}$ & 0.75 & $84 \%$ & 0 \\
\hline $\begin{array}{l}\text { Shuangan } \\
\text { Section, } \\
\text { Caigou Road }\end{array}$ & hard rock & 0.10 & $56^{\circ}$ & 0.9 & $10 \mathrm{~d}$ & 0.75 & $78 \%$ & 0.1 \\
\hline $\begin{array}{l}\text { Huliyu Section, } \\
\text { Huji Road }\end{array}$ & hard rock & 0.10 & $63^{\circ}$ & 0.9 & $10 \mathrm{~d}$ & 0.75 & $76 \%$ & 0.1 \\
\hline
\end{tabular}


Those data can be put into Equation 2-1 to calculate the magnitude of surface runoff intensity of each mountain section and determine the probability of flood damage, and make a preliminary judgment on the time node and the type of flood damage as follows:

Table 8 The probability of flood damage pre-judgement analysis table

\begin{tabular}{|l|l|l|l|l|l|}
\hline Highway name & $\begin{array}{l}\text { runoff } \\
\text { intensity } \\
\text { index P }\end{array}$ & $\begin{array}{l}\text { The possibility of } \\
\text { occurrence }\end{array}$ & Time & the type & control program \\
\hline North Jinwei Road & 0.6275 & Prone to happen & $\begin{array}{l}\text { June to } \\
\text { August }\end{array}$ & Slump & biological control \\
\hline $\begin{array}{l}\text { Sangyuan Section, } \\
\text { Maping Road }\end{array}$ & 0.6125 & Prone to happen & $\begin{array}{l}\text { June to } \\
\text { August }\end{array}$ & Slump & protecting mesh \\
\hline $\begin{array}{l}\text { Xinshuichang Section, } \\
\text { Yulong Road }\end{array}$ & 0.6275 & Prone to happen & $\begin{array}{l}\text { June to } \\
\text { August }\end{array}$ & $\begin{array}{l}\text { Landslid } \\
\text { e }\end{array}$ & protecting mesh \\
\hline $\begin{array}{l}\text { Yangjiayu Section, } \\
\text { Luoyang Road }\end{array}$ & 0.6125 & Prone to happen & $\begin{array}{l}\text { June to } \\
\text { August }\end{array}$ & Slump & protecting mesh \\
\hline $\begin{array}{l}\text { Chuancangyu Section, } \\
\text { Limutai Jingguan Road }\end{array}$ & 0.6275 & Prone to happen & $\begin{array}{l}\text { June to } \\
\text { August }\end{array}$ & Slump & protecting mesh \\
\hline $\begin{array}{l}\text { Gan Jian Section in the } \\
\text { front of Jin Qian Road }\end{array}$ & 0.5525 & Prone to happen & $\begin{array}{l}\text { June to } \\
\text { August }\end{array}$ & Collapse & $\begin{array}{l}\text { anti-sliding retaining } \\
\text { wall }\end{array}$ \\
\hline $\begin{array}{l}\text { Guoxi Section, } \\
\text { Guoying Road }\end{array}$ & 0.5525 & Prone to happen & $\begin{array}{l}\text { June to } \\
\text { August }\end{array}$ & Collapse & anchor retaining wall \\
\hline $\begin{array}{l}\text { Shuangan Section, } \\
\text { Caigou Road }\end{array}$ & 0.5675 & Prone to happen & $\begin{array}{l}\text { June to } \\
\text { August }\end{array}$ & $\begin{array}{l}\text { Debris } \\
\text { flow }\end{array}$ & $\begin{array}{l}\text { Retaining Structures\& } \\
\text { biological control }\end{array}$ \\
\hline $\begin{array}{l}\text { Huliyu Section, Huji } \\
\text { Road }\end{array}$ & 0.5675 & Prone to happen & $\begin{array}{l}\text { June to } \\
\text { August }\end{array}$ & $\begin{array}{l}\text { Debris } \\
\text { flow }\end{array}$ & $\begin{array}{l}\text { Retaining Structures\& } \\
\text { biological control }\end{array}$ \\
\hline
\end{tabular}

According to model, the researchers identified the high risk area of the slope disaster scientifically and accurately, and quickly identified the type of disaster through the identification technology, targeted to develop a scientific and feasible control scheme, so that the degree of damage of flood damage risk was with a minimum Level.

\section{The preventive effect of comparative analysis}

In 2015, the north mountainous areas by Jizhou District road on the slope of the flood damage hazard factors have been greatly curbed and eradicated, flood damage got the greatest degree of control, compared with 2014, the contrast diagram of preventive effect of the pre-identification technology is as follows:

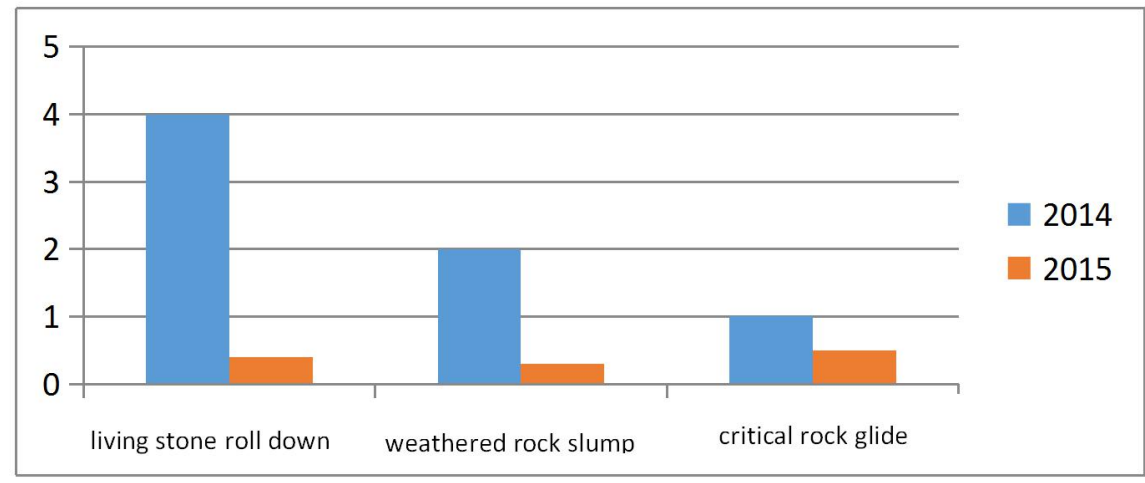

Chart2 the contrast of active flexible protecting nettings prevention adversities effect. 
By comparing the 2016 and 2015 on the loss varying diagram of the flood damage of highway upper slope, we can clearly see that the mountain slope flood damage identification technology is fruitful and remarkable in disaster reduction for reducing the loss of flood damage, improving the pre-disaster prevention, accuracy of disaster preventive work.

\section{Concluding remarks}

Flood damage prevention needs the researchers continue to strengthen the evaluation system research, identification methods to be innovative, taking efficient and scientific identification of technical guidance to deployment in prevention and control system, promoting the level of disaster prevention and reduction in mountainous roads.

\section{Reference}

[1].Jin-peng LIU, Road Waterlogging Disaster Identification Technology Research [J], Low-carbon World, 2015 (21) : 218-219

[2].Hai-jiang YANG, Wen-jun LIU, Mountainous Areas Highway Roadbed Waterlogging Disasters Cause Analysis and Prevention Measures to Explore [J], Urban Construction Theory Research, $2013(21): 36-39$

[3].Yong-ming GAO, jinni. Subgrade Waterlogging Hazard -Formative Factors Analysis and Prevention Measures [J], Traffic Management, 2012, 27 (2) : 56-58

[4].Qing-zhen HAO Mountainous Rural Road Waterlogging Forecast Evaluation Model Research [D], Chang 'an University, 2013 63- 68

[5].Sheng-li WEI Analysis of Road Waterlogging Disaster Prevention Countermeasures [J], East China Science and Technology: the Academic Version, 2013 (12) : 102-103

[6].Liang YAN, Yong DONG, Day South Slope Mountainous Road Waterlogging Disaster Distribution and Risk Assessment [J], Highway Traffic Technology: Application Technology, $2016(6): 38-43$

[7].Shuang LI, Hai-li ZHENG, Mountainous Road Waterlogging Disaster Engineering Protection Measures [J], Henan Science and Technology, 2014 (8 x) : 151-153 